\title{
Comparison between roll-over test and placental localization for early prediction of preeclampsia
}

\author{
Moneet Walia*, Aparajita Sophia D'souza, Garima Gupta
}

Department of Obstetrics \& Gynaecology, Christian Medical College, Ludhiana, Punjab, India

Received: 15 September 2015

Accepted: 29 September 2015

\author{
*Correspondence: \\ Dr. Moneet Walia, \\ E-mail: mohneetcmc@gmail.com
}

Copyright: $(\odot$ the author(s), publisher and licensee Medip Academy. This is an open-access article distributed under the terms of the Creative Commons Attribution Non-Commercial License, which permits unrestricted non-commercial use, distribution, and reproduction in any medium, provided the original work is properly cited.

\begin{abstract}
Background: Preeclampsia is a common disorder of pregnancy and a major cause of maternal, foetal and neonatal mortality and morbidity. The roll-over test is based on the observation that significant supine hypertension is present for a period of 8 to 10 weeks prior to the onset of preeclampsia. The objective of the present study was to study and compare roll-over test with placental localization for early prediction of preeclampsia.

Methods: In this prospective number bound study, a total of 200 unselected singleton pregnant females were included. All women were subjected to ultrasonography for placental localization at 24 weeks of gestation. They were subjected to roll-over test twice, first at 24 weeks and then at 28-30 weeks of gestation. Either the development of preeclampsia as per ACOG criteria or delivery was taken as end point in this study.

Results: Of 200 women, 148 had a central placenta and 52 had a unilateral placenta. 37 women had preeclampsia, out of which $68 \%$ had a unilateral placenta and $51 \%$ had positive roll-over test. However when the roll-over test was performed at 24 weeks, it was negative in all study cases. So it had got no role as an early predictor of preeclampsia.

Conclusions: This study concludes that ultrasonographic localization of the placenta seems to be a simple and easy to perform predictive test for incipient preeclampsia as compared to the roll-over test.
\end{abstract}

Keywords: Preeclampsia, Placental localization, Roll-over test

\section{INTRODUCTION}

Preeclampsia is a common disorder of pregnancy and a major cause of maternal, foetal and neonatal mortality and morbidity. ${ }^{1,2}$ The cause of preeclampsia must lie in the placenta as this disorder is specific to pregnancy and resolves shortly after delivery. Young teenage primigravidas are at a greater risk of developing preeclampsia. ${ }^{3}$ Many inroads have been made in reducing the perinatal impact of preeclampsia, however, when overt preeclampsia emerges, it carries with it significant maternal and foetal risk. From the standpoint of prevention, preeclampsia has remained a constant challenge. ${ }^{4}$ Prevention not only requires a knowledge of the pathophysiological mechanisms of the disease, but also the availability of methods of early prediction. ${ }^{5}$ In the past five decades, since Robertson and his colleagues showed that the process of preeclampsia already commences as early as the first trimester, attempts have been made to find a clinical method of predicting which patient would develop pregnancy induced hypertension and preeclampsia. ${ }^{6}$

The roll-over test was first described by Grant et al. It is based on the observation that significant supine hypertension is present for a period of 8 to 10 weeks prior to the onset of preeclampsia. The results of the roll-over test were highly variable among different investigations and there was poor reproducibility even in the same patient. $^{7}$ 
In humans, there is no proof that the anastomosis between the two uterine arteries is functional. When the placenta is laterally located, the uterine artery closer to the placenta has lower resistance than the one opposite to it. In patients with a centrally located placenta, both uterine arteries demonstrate similar resistance. ${ }^{8}$ There is reduced trophoblastic invasion in a laterally situated placenta, when the uteroplacental blood flow needs are mainly met by same side uterine artery. ${ }^{9}$

Noninvasive Doppler velocimetric studies of the uterine artery in the second trimester reveal an abnormal waveform indicating that the defective uterine perfusion is primarily a consequence of unilateral placental implantation when one uterine artery is the dominant supplier of the intervillous flow. ${ }^{10}$ These observations led to further studies to find out whether the lateral position of the placenta as seen by ultrasonography can be used to predict the development of preeclampsia. ${ }^{8}$

The ultimate goal in the management of preeclampsia is to be able to detect the disease in its incipient stage. More than a hundred clinical, biophysical and biochemical tests have been recommended for predicting the development of preeclampsia. Currently there is no ideal predictive test that fulfils the desired criteria. The value of the roll-over test remains controversial at the least. In the light of these observations, a prospective study was done to compare placental localization with the roll over test for early prediction of preeclampsia.

\section{METHODS}

This study was conducted at Acharya Vinobha Bhave Hospital attached to JNMC Wardha, starting from July 2003. This study was a prospective number bound study. It was a double blind study as the results of ultrasonography for placental localization and Roll-over test were neither revealed to the treating obstetrician (the one who diagnosed preeclampsia) nor to the patient.

A total of 200 pregnant women were included who fulfilled the following criteria.

\section{Inclusion criteria}

All singleton pregnant women attending the antenatal clinic (both outpatient and ward admissions) were included in this study.

\section{Exclusion criteria}

Pregnant women having essential hypertension, diabetes mellitus, chronic renal disease and severe anemia were excluded from the study. All cases that were lost to follow up were excluded.

Informed consent was taken from all the study subjects, all of them were subjected to a detailed history, general physical and obstetric examination at the time of their antenatal visits and at the time of their admission.
Ultrasonographic placental localization was done at 24 weeks of gestation. The placenta was classified as unilateral when $75 \%$ or more of the placental mass was towards one side of the midline. During same antenatal visit, all 200 cases were subjected to roll-over test. In the performance of this test, patient was placed in left lateral position, and after 20 minutes blood pressure was recorded form left arm lying parallel to body. When the diastolic blood pressure had become constant, the subject was turned to supine position and blood pressure was taken again. Roll-over test was interpreted as positive when increase in diastolic blood pressure of $20 \mathrm{~mm} \mathrm{Hg}$ or more had occurred on turning the patient form left lateral to supine position. Roll-over test was again performed at 28-30 weeks of gestation. Patient with positive roll-over test at any visit was considered as positive roll-over test case. Preeclampsia was defined as new onset hypertension (BP is > $140 \mathrm{mmHg}$ systolic or $>90 \mathrm{mmHg}$ diastolic) occurring in a pregnant woman after 20 weeks of gestation with proteinuria and pedal edema on the basis of the American Congress of Obstetricians and Gynecologists criteria. The end point of the study was either the development of preeclampsia or delivery. The accuracy of the tests in predicting the subsequent development of preeclampsia was analyzed using appropriate statistical tools.

\section{RESULTS}

A total of 200 unselected patients which fulfilled the inclusion and exclusion criterion were studied. The maternal and demographic profile was comparable in roll-over positive and negative groups, in laterally located and centrally located placenta groups and preeclamptic and normal groups as shown in table 1. Of the 200 women, 148 had central placenta and 52 had unilateral placenta. Roll-over test was positive in 72 women.

A total of 37 women developed preeclampsia, of which $25(68 \%)$ had unilaterally located placenta at 24 weeks of gestation. So, the risk of developing preeclampsia was 10 times greater in women with a laterally located placenta. The overall risk of developing preeclampsia with a laterally located placenta was 10.33 (odds ratio) and $95 \%$ confidence interval (CI) 2.40-10.88. This relationship was statistically highly significant (p value $<0.0001$ ) as shown in table 2 . Nineteen $(51 \%)$ women who had preeclampsia had positive roll-over test. So, the risk of developing preeclampsia was 2.2 times greater in women with positive roll-over test. The overall risk of developing preeclampsia with positive roll-over test was 2.191-(odds ratio) and 95\% confidence interval (CI) 1.051-4.457. This relationship was statistically significant ( $\mathrm{p}$ value- 0.03 ) as shown in table 2 .

However, when roll-over test was performed at 24 weeks of gestation, it was negative in all study cases. So it had got no role as a predictive test when performed at six months of gestation. Twenty seven women of our study underwent caesarian section. Operative finding of placental position was similar to one reported by ultrasonography in all these cases. 
Table 1: Socio-demographic profile of the study population.

\begin{tabular}{|c|c|c|c|c|c|c|}
\hline \multirow[t]{2}{*}{$\begin{array}{l}\text { Maternal } \\
\text { characteristics }\end{array}$} & \multicolumn{2}{|c|}{ Roll Over Test } & \multicolumn{2}{|c|}{ Ultrasonography } & \multicolumn{2}{|c|}{$\begin{array}{l}\text { Pregnancy Induced } \\
\text { Hypertension }\end{array}$} \\
\hline & $\begin{array}{l}\text { Positive } \\
(n=72)\end{array}$ & $\begin{array}{l}\text { Negative } \\
(\mathrm{n}-128)\end{array}$ & $\begin{array}{l}\text { Unilateral } \\
(\mathrm{n}=52)\end{array}$ & $\begin{array}{l}\text { Central } \\
(n=148)\end{array}$ & $\begin{array}{l}\text { Present } \\
(n=37)\end{array}$ & $\begin{array}{l}\text { Absent } \\
(n=163)\end{array}$ \\
\hline Age & $22+5.9$ & $23+5.3$ & $23.2 \pm 4.7$ & $24.3 \pm 6.1$ & $23 \pm 4.9$ & $24 \pm 4.3$ \\
\hline Weight & $63.8+5.9$ & $63.1 \pm 6.3$ & $64.2 \pm 8.3$ & $63.7 \pm 9.1$ & $65.2 \pm 6.8$ & $63.9 \pm 7.1$ \\
\hline Haemoglobin & $9.2 \pm 2.1$ & $9.1 \pm 2.3$ & $8.9 \pm 2.7$ & $9.3 \pm 2.4$ & $9.1 \pm 2.4$ & $9.2 \pm 1.9$ \\
\hline Gravidity & $2 \pm 1.2$ & $1.9 \pm 1.3$ & $1.9 \pm 1.7$ & $2 \pm 0.9$ & $1.9 \pm 1.4$ & $2 \pm 1.3$ \\
\hline Parity & $1 . \overline{7} \pm 0.8$ & $1.6 \pm 0.5$ & $1.6 \pm 0.9$ & $1.5 \pm 0.8$ & $1.6 \pm 0.7$ & $1.6 \pm 0.4$ \\
\hline Primigravida & 47 & 81 & 35 & 93 & 26 & 102 \\
\hline Multigravida & 25 & 47 & 17 & 55 & 11 & 61 \\
\hline $\begin{array}{l}\text { Low } \\
\text { Socioeconomic } \\
\text { status (104) }\end{array}$ & 39 & 65 & 32 & 72 & 19 & 85 \\
\hline
\end{tabular}

Table 2: Relationship of the placental position and development of Preeclampsia.

\begin{tabular}{|c|c|c|c|c|c|c|}
\hline & & \multicolumn{2}{|l|}{ PIH } & \multirow[b]{2}{*}{ Odds ratio } & \multirow[b]{2}{*}{$95 \%$ of $\mathrm{CI}$} & \multirow{2}{*}{$\begin{array}{c}\mathbf{X}^{2} \\
\& \\
\text { P value }\end{array}$} \\
\hline & & $\begin{array}{l}\text { Present } \\
(n=37)\end{array}$ & $\begin{array}{l}\text { Absent } \\
(n=163)\end{array}$ & & & \\
\hline \multirow[b]{2}{*}{$\begin{array}{l}\text { Placental } \\
\text { position }\end{array}$} & Central $(n=148)$ & $12(32 \%)$ & $136(83 \%)$ & & & \multirow[b]{2}{*}{$\begin{array}{l}\chi^{2}=40.77 \\
P-<0.0001\end{array}$} \\
\hline & Unilateral $(\mathrm{n}=52)$ & $25(68 \%)$ & $27(17 \%)$ & 10.33 & $4.70-23.42$ & \\
\hline \multirow[t]{2}{*}{ Roll-over test } & Positive $(n=72)$ & $19(51 \%)$ & $53(33 \%)$ & \multirow{2}{*}{2.191} & \multirow{2}{*}{$1.05-4.547$} & \multirow{2}{*}{$\begin{array}{l}\chi^{2} 4.457 \\
\text { P- } 0.031\end{array}$} \\
\hline & Negative $(n=128)$ & $18(49 \%)$ & $110(67 \%)$ & & & \\
\hline
\end{tabular}

Table 3: Comparison of placental localization \& roll over test as potential screening tests for preeclampsia.

\begin{tabular}{|c|c|c|c|c|c|c|}
\hline Test & Sensitivity & Specificity & $\begin{array}{l}\text { Positive } \\
\text { predictive } \\
\text { value }(\%)\end{array}$ & $\begin{array}{l}\text { Negative } \\
\text { predictive } \\
\text { value }(\%)\end{array}$ & $\begin{array}{l}\% \text { of false } \\
\text { negatives }\end{array}$ & $\begin{array}{l}\% \text { of false } \\
\text { positives }\end{array}$ \\
\hline $\begin{array}{l}\text { Placental } \\
\text { localization }\end{array}$ & 68 & 83 & 48 & 92 & 32 & 17 \\
\hline Roll over test & 51 & 67 & 26 & 86 & 49 & 33 \\
\hline
\end{tabular}

\section{DISCUSSION}

Preeclampsia is a complex clinical syndrome involving multiple organ systems. Many inroads have been made in reducing the perinatal impact of preeclampsia. However, when overt preeclampsia emerges, it carries with it significant maternal and fetal risk. From the stand point of prevention, preeclampsia has remained a constant challenge to the obstetrician. Prevention not only requires knowledge of pathophysiologic mechanism of this disease, but also methods of its early prediction.

The value of roll-over test lies in its simplicity. It requires no elaborate equipment or special skills and requires only minimal time investment. But results of roll-over test are highly variable among different investigators and also 
there is poor reproducibility in the same patient. Literature review reveals sensitivities varying between 0 to $93 \%$ and specificities between $54-91 \%$ and false positive results up to $90 \%$. In this study, out of 37 women who developed preeclampsia, 19 (51\%) had positive rollover test. However, when roll-over test was performed at 24 weeks, it was negative in all study cases. So, it had got no role as early predictive test when performed at 24 weeks of gestation.

In 1989,Koffinas et al showed that patients with unilateral placenta had a 2.8 times greater chance of having Preeclampsia. ${ }^{8}$ Schulman et al in same year supported these results with their finding that woman with preeclampsia had a dominant unilateral uteroplacental blood flow. $^{11}$ In 2005,Pai M. V. in his study concluded that women with unilateral placenta had a 2.7 fold increase in incidence of preeclampsia ${ }^{9}$. Lucy et al in their study on PIH and IUGR in 2007 also concluded that there was a fourfold increase with lateral placentation. $^{12}$

In the present study out of 200 women, 52 had a unilateral placenta and 148 had a central placenta. Out of 37 subjects $(18.5 \%$ incidence $)$ who developed preeclampsia, $25(68 \%)$ had a unilaterally located placenta, whereas only $12(32 \%)$ had a centrally located placenta. This result is in accordance with Kakkar et al, who concluded that females with a laterally located placenta determined at age $18-24$ weeks gestation have 5 times greater risks of developing preeclampsia. ${ }^{13}$

\section{CONCLUSION}

From the present study, it is evident that an excellent correlation exists between placental laterality and the development of preeclampsia. Females with a unilateral placenta have a 10 times greater risk of developing preeclampsia. More careful obstetric management may be required in these pregnancies to achieve a more favourable maternal and perinatal outcome. So, it can be concluded from the present study that ultrasonographic localization of the placenta seems to be a simple, easy and non-invasive test to perform for prediction of incipient pregnancy induced hypertension. Predictability parameters of unilateral placenta were better than rollover test. Roll-over test has got no value for early prediction of incipient preeclampsia at 24 weeks of gestation.

Funding: No funding sources Conflict of interest: None declared

Ethical approval: The study was approved by the Institutional Ethics Committee

\section{REFERENCES}

1. Kaunitz AM, Hughes JM, Grimes DA, Rochat RW, Kafrisen ME. Causes of maternal mortality in the United States. Obstet Gynecol. 1985; 65:605-12.

2. Knutzen VK, Davey DA: Hypertension in pregnancy, perinatal mortality and causes of fetal death. S Afr Med J. 1977;51:675-9.

3. Scott JS: pregnancy toxaemia associated with hydatidiform mole. J Obst Gynecol Br. Empire. 65; 689-701.

4. Karbhari D, Harrigan JT, Lamagra R: The supine pressure test as a predictor of incipient preeclampsia. American Journal of Obstetrics and Gynaecology. 1977;127:620-2.

5. Dekker GA: Prediction and pregnancy induced hypertensive disorders: a clinical and pathophysiologic study (Thesis). Rotterdam: Erasmus University. 1989.

6. Robertson WB, Brosens I, Dixon G: The pathological response of the vessels of the placental bed to hypertensive pregnancy. J. Pathol Bactriol. 1967;93:581-92.

7. Dekker GA, Sibai BM: Early detection of preeclampsia. Am J. Obstet Gynecol. 1991;165:16072.

8. Koffinas AD, Penry M, Swain M, Hatijis CG: Effect of placental laterality on uterine artery resistance and development of preeclampsia and intrauterine growth retardation. Am J. Obstet Gynecol. 1989;161:1536-9.

9. Pai MV, Pillai J: Placental laterality by ultrasound a simple yet reliable predictive test for preeclampsia. J Obstst Gynecol India. 2005;65:431-3.

10. Fleischer A, Schulman H, Farmakides $G$ et al: Uterine artery Doppler velocimetry in pregnant women with hypertension. Am J Obstet Gynecol. 1986;154:806-13.

11. Schulman H, Ducey J, Farmakides G et at: The significance of divergernt systolic-diastolic ratios. Am J.tet. Gynaecol. 1987;157:1539-44.

12. Kalanithi LE, Illuzzi JL, Nossov VB, et al. Intrauterine growth restriction and placental location. J Ultrasound Med. 2007; 26:1481-9.

13. Kakkar T, Singh V, Razdan R, et al. Placental Laterality as a Predictor for Development of Preeclampsia. J Obstet Gynecol India. 2013;63(1):22-5.

Cite this article as: Walia M, D'ouza AS, Gupta G. Comparison between roll-over test and placental localization for early prediction of preeclampsia. Int $\mathbf{J}$ Reprod Contracept Obstet Gynecol 2015;4:1710-3. 